\title{
Interest Rate Pass-Through, Monetary Policy Rules and Macroeconomic Stability *
}

\author{
Claudia Kwapil ${ }^{\dagger} \quad$ Johann Scharler ${ }^{\ddagger}$
}

March 2006

\begin{abstract}
In this paper we analyze equilibrium determinacy in a sticky price model in which the pass-through from policy rates to retail interest rates is sluggish and potentially incomplete. In addition, we empirically characterize and compare the interest rate pass-through process in the euro area and the U.S. We find that if the pass-through is incomplete in the long run, the standard Taylor principle is insufficient to guarantee equilibrium determinacy. Our empirical analysis indicates that this result might be particularly relevant for bank-based financial systems as for instance that in the euro area.
\end{abstract}

Keywords: Interest Rate Pass-Through, Interest Rate Rules, Equilibrium Determinacy, Stability

JEL codes: E32, E52, E58

${ }^{*}$ The views expressed in this paper are those of the authors and in no way commit the Oesterreichische Nationalbank.

${ }^{\dagger}$ Oesterreichische Nationalbank, Economic Analysis Division, Otto-Wagner-Platz 3, POB 61, A-1011 Vienna, Austria, Phone (+43-1) 404 20-7415, Fax (+43-1) 404 20-7499, e-mail: claudia.kwapil@oenb.at.

$\ddagger$ Oesterreichische Nationalbank, Economic Analysis Division, Otto-Wagner-Platz 3, POB 61, A-1011 Vienna, Austria, Phone (+43-1) 404 20-7419, Fax (+43-1) 404 20-7499, e-mail: johann.scharler@oenb.at. 


\section{Introduction}

The stability properties associated with monetary policy rules have attracted a substantial amount of attention. In particular, monetary policy rules give rise to a determinate equilibrium if the implied response to inflation is sufficiently strong. To avoid indeterminacy, nominal interest rates have to respond sufficiently to an increase in inflation to raise the real interest rate. Hence, the nominal rate has to respond at least one-for-one to changes in the (expected) inflation rate to guarantee a unique and stable equilibrium. This result is referred to as the Taylor principle (Woodford, 2003). Otherwise, the equilibrium is indeterminate and fluctuations resulting from self-fulfilling revisions in expectations become possible. Intuitively, if nominal rates do not adjust sufficiently, a rise in expected inflation leads to a decrease in the real interest rate, which stimulates aggregate demand. Higher aggregate demand results in an increase in inflation, and consequently the initial expectation is confirmed. Several studies argue that the comparatively successful conduct of monetary policy since the early 1980s is primarily due to the implementation of an appropriate policy rule, that is, a rule that satisfies the Taylor principle (see e.g. Judd and Rudebush, 1998; Taylor, 1999; Clarida et al., $1998,2000)^{1}$

Empirically it appears that retail interest rates respond less than one-forone to policy rates (e.g. De Bondt, 2005; Ehrmann et al., 2003). Moreover, retail rates are likely to influence aggregate demand at least to some extent. Thus, it seems conceivable that although monetary policy is tightened sufficiently, obeying the Taylor principle, retail interest rates do not respond

\footnotetext{
${ }^{1}$ Nevertheless, this view is not without controversy. In a series of papers, Orphanides $(2005,2003,2002)$ argues that the instability observed in the 1970s was the consequence of too ambitions goals for output stabilization and too pessimistic real-time estimates of the output gap.
} 
sufficiently to ensure that real rates are stabilizing. This appears to be particularly relevant for the euro area, which is generally thought to be an example of a bank-based financial system (Allen and Gale, 2000). Berger and Udell (1992) point out that liquidity smoothing is typical for environments, in which close customer relationships develop over time. That is, banks with close ties to their customers may offer implicit interest rate insurance and hold interest rates relatively constant despite changes in the stance of monetary policy.

In the present paper we analyze the stability properties of a simple sticky price model in which retail interest rates adjust sluggishly to changes in policy rates and the pass-through is potentially incomplete. In particular, we introduce costly financial intermediation, which gives rise to sticky retail interest rates. Although we model limited interest rate pass-through in a highly simplified way without providing explicit micro foundations, we still believe that this feature of the model represents an important aspect of the monetary transmission mechanism that is missing in most other models.

Several studies find that the conditions for a determinate equilibrium have to be modified under certain circumstances. Edge and Rudd (2002) and Roisland (2003) claim that the presence of taxes on capital income requires a strengthening of the Taylor principle. Galí et al. (2004) introduce rule-ofthumb consumers in a sticky-price model and show that the Taylor principle is no longer sufficient for determinacy. De Fiore and Liu (2005) find that for a small open economy the degree of openness to trade is critical for stability. However, to our knowledge the idea that the financial system and in particular the interest rate pass-through may impact upon the determinacy of the equilibrium has not been explored. Thus, the present paper contributes to the literature in this respect. 
Our main result is that if the pass-through to retail interest rates is incomplete in the long run, the standard Taylor principle no longer guarantees a determinate equilibrium. Put differently, the coefficient on inflation in the Taylor rule may have to be well above unity to be consistent with a unique and stable equilibrium.

In addition, we explore whether limited interest rate pass-through is likely to be important in a quantitative sense. We provide empirical evidence on the pass-through process for the euro area and the U.S. as examples of bankbased and market-based systems, respectively. We find that the pass-through is less complete in the euro area in comparison to the U.S. Based on our empirical results and the monetary policy reaction functions estimated in the literature, we conclude that limited pass-through does not appear to be a source of instability neither in the euro area nor in the U.S.

The paper is structured as follows: Section 2 describes a simple model, which will be the basis of our analysis. The link between limited pass-through and determinacy is analyzed in Section 3. Section 4 reports the results of our empirical analysis and Section 5 discusses the implications of the empirical results in terms of determinacy. Section 6 concludes the paper.

\section{Model}

The model we employ is a standard New Keynesian business cycle model closely related to Woodford (2003), hence the description will be brief. The model consists of firms, a financial intermediary sector and households. The only asset available in the economy is a risk-less, nominal, one-period bond, $B_{t}$, that pays an interest rate of $R_{t}$. However, it is assumed that households cannot buy bonds directly, but have to deposit funds, $D_{t}$, at a financial intermediary instead. The financial intermediary uses the deposits of the 
households and buys bonds. Moreover, we assume that financial intermediation is costly and that this cost is a function of the change in interest rates. This assumption allows us to introduce interest rate smoothing into the model in a simple, reduced-form way. The financial intermediaries maximize profits, given by $R_{t} B_{t}-\Psi_{t} R_{t}^{D} D_{t}$, by the choice of bonds and deposits, which yield a gross interest rate of $R_{t}^{D} . \Psi_{t}>1$ represents an intermediation cost. In particular, we assume that $\Psi_{t}=\psi_{0}\left(\frac{R_{t}^{D}}{\left(R_{t-1}^{D}\right)^{\nu}}\right)^{\psi}$, where $\psi_{0}>0$ and $\psi>0$. The parameter $\psi_{0}$ is chosen such that $\Psi_{t}>1$. Since banks do not have an incentive to hold reserves, it follows that $D_{t}=B_{t}$. Taking a log-linear approximation of the bank's necessary condition gives

$$
\hat{R}_{t}^{D}=\frac{1}{1+\psi} \hat{R}_{t}+\frac{\psi \nu}{1+\psi} \hat{R}_{t-1}^{D},
$$

where hatted variables denote percentage deviations from the steady state. Thus, $1 /(1+\psi)$ determines the immediate pass-through from the bond yield, which is assumed to be the interest rate targeted by monetary policy, and $\psi \nu /(1+\psi)$ determines the persistence of the deposit rate.

Households maximize their expected lifetime utility

$$
E_{0} \sum_{t=0}^{\infty} \beta^{t}\left(\frac{C_{t}^{1-\sigma}}{1-\sigma}-\frac{L_{t}^{1+\eta}}{1+\eta}\right)
$$

where $\sigma>0$ and $\eta>0, \beta$ is a discount factor, $C_{t}$ is consumption of a composite good in period $t$ and $L_{t}$ denotes labor supply in period $t$. The composite consumption good, $C_{t}$, is a CES aggregate of the quantities of differentiated goods, $C_{t}(i)$, where $i \in(0,1): C_{t}=\left(\int_{0}^{1} C_{t}(i)^{\frac{\epsilon-1}{\epsilon}} d i\right)^{\frac{\epsilon}{\epsilon-1}}$. Households enter each period with bank deposits carried over from the previous period, $D_{t-1}$. Furthermore, households supply $L_{t}$ units of labor at a nominal wage of $W_{t}$. The representative household owns firms and the financial intermediaries and receives dividends. Hence, deposits evolve according to: $D_{t}=W_{t} L_{t}+R_{t}^{D} D_{t-1}-P_{t} C_{t}+\Pi_{t}$, where $P_{t}$ denotes the aggregate price index 
and $\Pi_{t}$ denotes dividends distributed at the end of the period. Household behavior is summarized by the usual consumption Euler equation and a labor supply equation:

$$
\begin{gathered}
\hat{C}_{t}=-\frac{1}{\sigma}\left(\hat{R}_{t}^{D}-E_{t}\left(\hat{\pi}_{t+1}\right)\right)+E_{t}\left(\hat{C}_{t+1}\right), \\
\hat{W}_{t}-\hat{P}_{t}=\eta \hat{L}_{t}+\sigma \hat{C}_{t}
\end{gathered}
$$

where $\pi_{t}=\log P_{t}-\log P_{t-1}$ is the inflation rate. The business sector of the economy consists of a continuum of monopolistically competitive firms normalized to unit mass. Each firm $i$ hires labor, $H_{i t}$, and produces output according to: $Y_{i t}=H_{i t}^{1-\alpha}$, where $\alpha \in(0,1)$. Furthermore, we assume staggered price setting and allow inflation to depend on its own history, as in Galí et al. (1999) and Galí et al. (2001). That is, each period, a fraction $(1-\theta)$ of the firms is able to readjust its price. Moreover, a fraction $(1-\omega)$ of these firms that can set prices in the current period resets prices optimally, the remaining firms follow a backward looking rule. As shown in Galí et al. (2001), these assumptions on the pricing behavior of firms give rise to a Phillips curve of the form:

$$
\hat{\pi}_{t}=\delta \widehat{m c}_{t}+\beta \theta \phi^{-1} E_{t} \hat{\pi}_{t+1}+\omega \phi^{-1} \hat{\pi}_{t-1},
$$

where $\delta=\frac{(1-\theta)(1-\theta \beta)(1-\alpha)(1-\omega)}{(1+\alpha(\epsilon-1))} \phi^{-1}, \phi=\theta+\omega(1-\theta(1-\beta))$ and $m c_{t}$ denotes average real marginal cost.

Using the market clearing conditions $Y_{t}=C_{t}$ and $H_{t}=L_{t}$ and (4), the log-linearized model can be written as:

$$
\begin{gathered}
\hat{Y}_{t}=-\frac{1}{\sigma}\left(\hat{R}_{t}^{D}-E_{t}\left(\hat{\pi}_{t+1}\right)\right)+E_{t}\left(\hat{Y}_{t+1}\right) \\
\hat{\pi}_{t}=\delta \gamma \hat{Y}_{t}+\beta \theta \phi^{-1} E_{t} \hat{\pi}_{t+1}+\omega \phi^{-1} \hat{\pi}_{t-1}, \\
\hat{R}_{t}^{D}=\lambda_{1} \hat{R}_{t}+\lambda_{2} \hat{R}_{t-1}^{D}
\end{gathered}
$$


where $\gamma=\frac{1+\eta}{1-\alpha}-1+\sigma, \lambda_{1}=1 /(1+\psi)$ and $\lambda_{2}=\psi \nu \lambda_{1}$. The intertemporal IS curve in (6) and the Phillips curve in (7) constitute a baseline model widely used for the evaluation of monetary policy (see e.g. Clarida et al., 1999). The dynamics of the deposit rate is determined by (8) where $\lambda_{1}$ captures the instantaneous pass-through from policy to deposit rates and $\lambda_{2}$ determines the degree of persistence. To fully describe the equilibrium dynamics of the model, an interest rate rule as a description of monetary policy is added. We assume that monetary policy targets the interest rate on bonds, $R_{t}$ :

$$
\hat{R}_{t}=\rho \hat{R}_{t-1}+(1-\rho)\left(\kappa_{\pi} \hat{\pi}_{t}+\kappa_{y} \hat{Y}_{t}\right)
$$

where $\rho$ determines the degree of monetary policy inertia and $\kappa_{\pi}, \kappa_{y}$ characterize the response of the policy rate to inflation and output, respectively.

\section{Interest Rate Pass-Through and Determi- nacy}

In this section we analyze how the interest rate pass-through influences the stability properties of the model. The model (6) - (9) can be conveniently written as $A E_{t}\left(u_{t+1}\right)=B u_{t}$, where $u_{t}=\left(\hat{Y}_{t}, \hat{\pi}_{t}, \hat{R}_{t}, \hat{R}_{t}^{D}\right)^{\prime}$ and $A$ and $B$ are coefficient matrices with entries that are functions of the structural parameters. Determinacy or stability of the rational-expectations equilibrium corresponds to the case where the number of eigenvalues of $A^{-1} B$ outside the unit circle is equal to the number of predetermined variables (Blanchard and Kahn, 1980). We simulate the model to see how the parameters $\lambda_{1}$ and $\lambda_{2}$ influence this stability condition.

The following parameter values are chosen: The time discount factor $\beta$ is set to 0.99 . The coefficients $\sigma$ and $\eta$, which determine the intertemporal elasticity of substitution and the labor supply elasticity, are both set equal to 
2. $\epsilon$ is set to 11 , which corresponds to a steady-state mark-up of 10 percent. $\alpha$ is set to 0.33 . Furthermore, $\omega=0.3$, which means that 30 percent of the firms follow a backward-looking pricing rule. Prices are assumed to be fixed on average for four quarters, therefore $\theta=0.75$. This calibration of the price-setting behavior is roughly in line with the recent empirical evidence (see Leith and Malley, 2005). According to empirical evidence reported in Gerdesmeier and Roffia (2004) for the euro area and in Clarida et al. (2000) for the U.S., we set $\rho=0.8$.

For simplicity, consider the case where monetary policy does not react to the output gap, that is $\kappa_{y}=0$. Furthermore, let $\lambda=\lambda_{1} /\left(1-\lambda_{2}\right)$ denote the long-run effect of the policy interest rate on the deposit rate. Figure 1 displays the frontier that divides the parameter space $\left(\lambda, \kappa_{\pi}\right)$ into regions corresponding to determinate and indeterminate equilibria. The frontier is downward sloping and convex to the origin. Points to the right of the frontier correspond to parameter combinations that are consistent with a determinate equilibrium. Points to the left lead to indeterminacy. Thus, the frontier defines the lower bound on $\kappa_{\pi}$, denoted by $\bar{\kappa}_{\pi}$, where $\kappa_{\pi}>\bar{\kappa}_{\pi}$ is consistent with a determinate equilibrium. Clearly, a lower long-run pass-through requires a stronger response of monetary policy to inflation to ensure determinacy. In particular, our simulations show that for $\kappa_{y}=0, \bar{\kappa}_{\pi}$ corresponds to $1 / \lambda$. Thus, the Taylor principle has to be modified in this environment to $\kappa_{\pi} \lambda>1$. For values of $\kappa_{\pi}$ below $\bar{\kappa}_{\pi}$, the equilibrium is indeterminate and fluctuations resulting from self-fulfilling revisions in expectations become possible. The intuition is straightforward: For low values of $\lambda$, changes in the policy interest rate are to a large extent absorbed by the banking sector and not passed on to households. Hence, if expected inflation increases, monetary policy has to be tightened considerably to have a stabilizing effect on aggregate demand. 
Note that what matters is the long-run pass-through. Thus, high persistence, $\lambda_{2}$, compensates for a low initial pass-through, $\lambda_{1}$. For $\lambda=1$ the associated value of $\bar{\kappa}_{\pi}$ is unity. Hence, for a complete pass-through at least in the long run, we obtain the standard Taylor principle.

So far we have restricted our analysis to the case $\kappa_{y}=0$. For $\kappa_{y}>0$, the frontier shifts down, since the response of interest rates to the output gap has to be taken into account. According to the Phillips curve, permanently higher inflation implies a permanently higher output gap, which will lead to higher interest rates in the long run (see Woodford, 2003). However, for empirically plausible values for $\kappa_{y}$ the implications for $\bar{\kappa}_{\pi}$ are negligible.

Figure 1: Regions of Determinacy and Indeterminacy

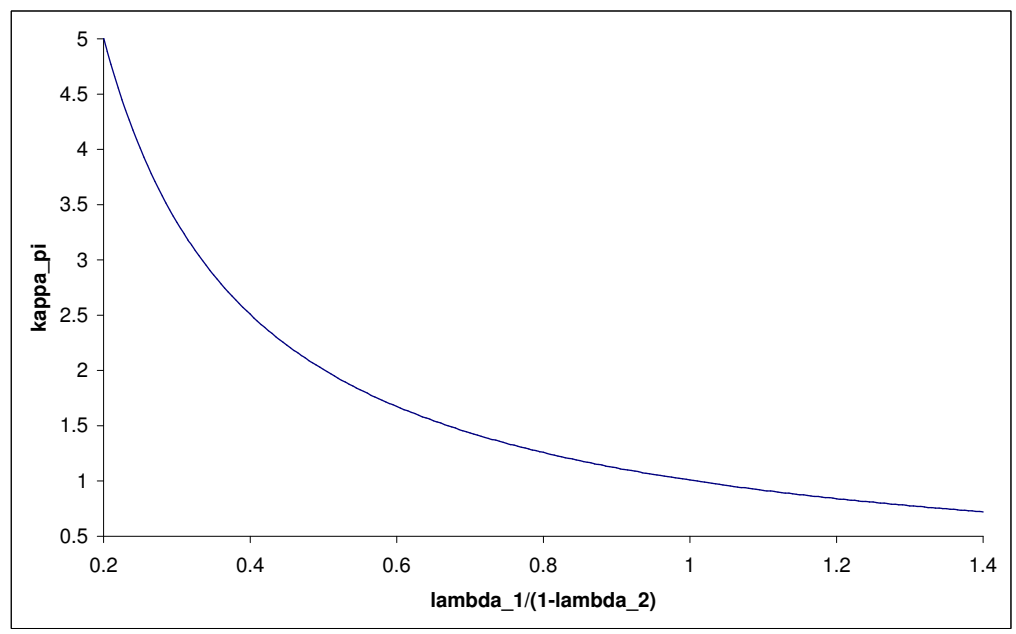

Notes: The frontier divides the parameter space $\left(\lambda, \kappa_{\pi}\right)$ into regions corresponding to determinate and indeterminate equilibria. Points to the right of the frontier correspond to parameter combinations that are consistent with a determinate equilibrium.

Note that according to (9) the nominal interest rate adjusts to contem- 
poraneous deviations of inflation and output from their steady state values, whereas empirical evidence indicates that monetary policy acts in a forward-looking manner. In models with forward-looking interest rate rules, the Taylor principle is still a necessary condition for equilibrium determinacy, although it is no longer sufficient. In particular, if the nominal interest rate is adjusted in response to expected inflation, determinacy additionally requires that $\kappa_{\pi}$ is not too large (Woodford, 2003). However, the upper bound on $\kappa_{\pi}$ associated with determinacy appears to be extremely large for plausible parameterizations and is satisfied by empirically estimated interest rate rules. Thus, focusing our analysis on the class of non-forward-looking interest rate rules does not appear to be overly restrictive.

\section{Empirical Analysis}

In this section we empirically compare the interest rate pass-through across financial systems, where the euro area and the U.S. are taken as examples of a bank-based and a market-based system, respectively. The empirical analysis is based on (8) which describes the dynamics of the retail interest rate in the model. As our model does not explicitly account for investment, we interpret $C_{t}$ more broadly as the interest-sensitive part of GDP and not just as consumption spending. Hence, our empirical analysis is based on a wide spectrum of retail rates relevant for households and firms. The empirical strategy consists of the following steps: We start by testing for unit roots in our retail and monetary policy rate series, where we take the three-month money market rate as a proxy for the policy rate. For those series, which are found to be integrated, we proceed with testing for cointegration between retail and policy rates, since this would suggest to generalize our estimating equation to an error-correction model. Finally, we use an equation similar to 
(8) to estimate the pass-through in the short and in the long run.

\subsection{Data}

Due to differences in the statistical systems, it is hard to find equivalent retail interest rate series for the U.S. and the euro area. For bank deposit rates we aim for interest rates with similar maturities, while regarding lending rates we take loans that cover businesses and consumers over short as well as long horizons. For the U.S. we analyze four different bank deposit rates with maturities between one month and one year. For the euro area we include five different deposit rates: sight deposits, saving deposits (redeemable at notice below and above three months) and time deposits (with agreed maturities below and above two years). Moreover, we incorporate three different bank lending rates for the U.S. in our analysis, which cover short-term loans for businesses, short-term consumer credits as well as mortgage loans for businesses and households. For the euro area we include four different lending rates, namely business loans (below and above one year) and short-term loans as well as mortgage loans to households. All interest rates are monthly data, with the exception of consumer credit rates in the U.S., which are reported with a quarterly frequency. The time period we consider starts in January 1995 and ends in September 2003, because no longer aggregated time series are available for the euro area. ${ }^{2}$ There are a few exceptions where the time series starts little later than January 1995. Details on the time period covered by the data as well as the source of the data are found in Appendix A.

The various deposit and lending rates give an overview of the different

\footnotetext{
${ }^{2}$ In 2003 the ECB changed the statistical system for collecting retail interest rates and stopped producing the series mentioned above in September 2003. The new series that starts in 2003 is not compatible with the one we are using.
} 
dimensions of the pass-through process. However, in order to have one representative value for deposit as well as for lending rates, we construct weighted averages of these interest rates. The weights are chosen according to the importance of the individual lending and deposit categories in the portfolio of commercial banks. For the U.S. we take the weights from the Flow of Funds Accounts of the United States (Z.1), which are published by the Board of Governors of the Federal Reserve System. ${ }^{3}$ The three lending rates mentioned above are taken as representative interest rates for the portfolio items 'bank loans n.e.c.', 'consumer credit' and 'mortgages', which altogether amount to 95 percent of total loans of the commercial banking sector. ${ }^{4}$ Time and saving deposits are also included in the Flow of Funds Accounts, however, unfortunately not according to their maturities. Thus, we are not able to set up a weighted average for U.S. bank deposit rates. For weighting retail rates in the euro area we can directly refer to balance sheet information from Monetary Financial Institutions (MFI), which are published in the statistical section of the ECB's Monthly Bulletin. ${ }^{5}$

\subsection{Unit Root and Cointegration Tests}

We first test for unit roots in money market and retail interest rates in our sample using the Augmented Dickey-Fuller (ADF) test (see Dickey and Fuller, 1979; Said and Dickey, 1984) and the Phillips-Perron (PP) test (see

\footnotetext{
${ }^{3}$ Table L.109 gives the levels of the portfolio of U.S. commercial banks.

${ }^{4}$ In 2003 'bank loans n.e.c.' constitute 29 percent, 'consumer credit' 15 percent and 'mortgages' 51 percent of total loans from commercial banks.

${ }^{5}$ Table 2.4 of the ECB's Monthly Bulletin gives the amount of loans from monetary financial institutions according to counterpart, type and maturity. In 2003 the shares of business loans, short-term loans to consumers and mortgage loans to consumers were 52 percent, 8 percent and 40 percent, respectively. Table 2.5 of the ECB's Monthly Bulletin gives the amount of deposits held with MFIs by counterpart and instrument. Sight deposits, saving deposits and time deposits amounted to 38 percent, 31 percent and 31 percent of total deposits held by non-financial corporations and households in the euro area, respectively.
} 
Phillips, 1987; Phillips and Perron, 1988). Ng and Perron (2001) argue that many unit root tests suffer from low power and size distortions. Thus, we also apply the four tests developed by $\mathrm{Ng}$ and Perron (2001) (NgP tests) with improved size and power. ${ }^{6}$

Detailed test results are reported in Appendix B. In all but one case the results of the $\mathrm{ADF}$ test and the $\mathrm{PP}$ test suggest that the series are $I(1)$ and these results are confirmed by the four $\mathrm{NgP}$ tests. The one exception is the interest rate on sight deposits in the euro area, where the PP test argues in favor of $I(1)$, while the ADF test and the four $\mathrm{NgP}$ tests indicate that the time series is $I(2)$. Hence, we follow the majority of the tests and take this series to be $I(2)$.

As money market rates and retail interest rates are $I(1)$, with the exception of the interest rate on sight deposits in the euro area, we proceed with testing for cointegration between market and retail rates. The series for the interest rates on sight deposits in the euro area is excluded from this analysis. Again we apply a battery of tests. First, we apply the OLS-residual-based tests proposed by Engle and Granger (1987) (ADF test) and Phillips and Ouliaris (1990) (PP test). In addition, we use the more recent tests developed by Perron and Rodriguez (2001) (PR test), who use GLS-detrended data and construct test statistics similar to those by Ng and Perron (2001). In particular, we apply two of the PR tests, which are modified forms of the $\mathrm{PP}$ test statistics (MZa) and the ADF test (ADF-GLS).

For the U.S. the standard tests (ADF test and PP test) suggest that all retail interest rates (lending as well as deposit rates) are cointegrated (at least at the 10 percent level), while the PR tests reject the hypothesis of

\footnotetext{
${ }^{6}$ These test statistics from Ng and Perron (2001) are modified forms of the PP test statistics (MZa, MZt), the test statistic suggested by Bhargava (1986) (MSB), and the Point Optimal statistic from Elliot et al. (1996)(MPT).
} 
cointegration. For the euro area the standard tests do not give a uniform answer for all the series. While long-term lending rates are more likely to be cointegrated, short-term lending rates and deposit rates do not seem to have a cointegrating relationship with money market rates. However, as in the case of U.S. retail rates, the new PR tests clearly argue against cointegration for all series. Detailed test results can be found in Appendix B.

As the tests suggested by Perron and Rodriguez (2001) achieve important power gains through the use of GLS-detrended data, we conclude that none of the retail rates is cointegrated with the money market rate.

\subsection{Long-Run Pass-Through}

We estimate the pass-through in the short and in the long run based on (8). To take the non-stationarity of the data into account, the equation is estimated with differenced data. Since our data series do not appear to be cointegrated we do not include an error-correction term. However, the equation is generalized to an autoregressive distributed-lag (ADL) model by adding additional lags of the money market rate and the retail interest rate. We choose the number of lags according to the Akaike Information Criterion with the maximum number of lags set at six.

$$
\Delta R_{t}^{D}=c_{0}+\sum_{i=0}^{i_{\max }} a_{i} \Delta R_{t-i}+\sum_{j=1}^{j_{\max }} b_{j} \Delta R_{t-j}^{D}
$$

While the short-run pass-through is equal to $a_{0}$, the long-run multiplier $\lambda$ is calculated according to

$$
\lambda=\frac{\sum_{i=0}^{n} a_{i}}{1-\sum_{j=1}^{m} b_{j}}
$$

where $n$ and $m$ denote the number of lags chosen as described above.

Tables 1 and 2 give the results for the U.S. and the euro area, respectively. As shown in the upper block of Table 1, in the U.S. the long-term pass- 
through of money market rates to bank deposit rates is nearly complete. For deposits with short maturities (one and three months) the null hypothesis that the long-run pass-through is equal to one is not rejected. For deposit rates with maturities of six months and one year the long-run pass-through appears to be slightly below unity. Changes in money market rates are passed on quickly. In some cases in the short run even to a larger extent than in the long run.

In the lower block of Table 1 we see that for U.S. lending rates the picture is less clear: On the one hand, mortgage rates in the U.S. are smoothed heavily. In the long run only 29 basis points are passed on from a 100 basis point change in the money market rate. On the other hand, in the case of short-term business loans the long-run pass-through is complete. Statistically it is not significantly different from one. Also, the extent of how much is passed on immediately differs substantially between the various lending rates. Furthermore, the weighted average of the long-run pass-through to lending rates in the U.S. amounts to 0.57. Put differently, in the long run slightly below 60 percent of a change in short-term market rates are passed on to U.S. borrowers, while the remaining fraction is absorbed by the banking sector.

The upper block of Table 2 gives the results for deposit rates in the euro area. There we observe a much smaller pass-through to deposit rates than in the U.S. The long-run pass-through ranges between 0.27 for saving deposits with a maturity of less than three months and 0.66 for time deposits with a maturity of up to two years. Our estimates of the final pass-through are smaller for all categories than those reported in De Bondt (2005). ${ }^{7}$ However, the relative size of the long-run pass-through to the various deposit rates is the same in both analyses. The immediate pass-through is quite heteroge-

\footnotetext{
${ }^{7}$ De Bondt (2005) uses different data and a shorter time period and assumes that nearly all series are cointegrated.
} 
Table 1: Short- and Long-Run Pass-Through in the U.S., 1995-2003

\begin{tabular}{l|cccc}
\hline \hline & \multicolumn{2}{|c}{$\begin{array}{c}\text { short-run } \\
\text { pass-through }\end{array}$} & \multicolumn{2}{c}{$\begin{array}{c}\text { long-run } \\
\text { pass-through }\end{array}$} \\
\hline Deposit rates & & & & \\
TCD, 1 month & 0.76 & $(0.06)$ & 1.04 & $(0.03)$ \\
TCD, 3 months & 1.02 & $(0.01)$ & 1.01 & $(0.01)$ \\
TCD, 6 months & 1.03 & $(0.05)$ & 0.92 & $(0.04)$ \\
US deposits, 1 year & 1.08 & $(0.09)$ & 0.74 & $(0.08)$ \\
\hline Lending rates & & & & \\
Business, short-term & 0.44 & $(0.06)$ & 1.04 & $(0.05)$ \\
Mortgage, long-term & 0.71 & $(0.16)$ & 0.29 & $(0.28)$ \\
Consumers, short-term & 0.30 & $(0.12)$ & 0.36 & $(0.08)$ \\
Weighted average & 0.79 & $(0.15)$ & 0.57 & $(0.11)$ \\
\hline \hline
\end{tabular}

Notes: TCD abbreviates Time Certificates of Deposit. Standard errors in parentheses. The standard errors for the long-term pass-through are calculated according to the delta method (e.g. Greene, 2000, p. 330). The sample of mortgage lending rates in the U.S. was shortened to 2000, where there seems to be a structural break. After 2000 the short- as well as the long-run pass-through decline significantly. Because of the structural break in the mortgage rate, the sample of the weighted average was also adjusted to 1995-2000.

neous in the euro area. For deposit rates with short maturities, a third to half of the amount passed on in the long run is passed on within one month. For deposit rates with longer maturities, the short-run and the long-run passthrough are roughly equal. On average the long-run pass-through to deposit rates in the euro area amounts to 0.32 .

From the lower block of Table 2 we see the results for lending rates in the euro area. There the long-run pass-through ranges between 0.43 for shortterm loans to households and 0.69 for business loans with a maturity of up to one year. Like in the case of deposit rates, our estimates of the long-run pass-through to lending rates are smaller than those in De Bondt (2005). The weighted average of lending rates, which summarizes short-term and long-term loans to businesses and households in the euro area, lies at 0.48 . Hence, in the euro area approximately 50 percent of a money market rate 
Table 2: Short- and Long-Run Pass-Through in the Euro Area, 1995-2003

\begin{tabular}{l|cccc}
\hline \hline & \multicolumn{2}{|c}{$\begin{array}{c}\text { short-run } \\
\text { pass-through }\end{array}$} & $\begin{array}{c}\text { long-run } \\
\text { pass-through }\end{array}$ \\
\hline Deposit rates & & & & \\
Saving deposits, $<3$ months & 0.09 & $(0.02)$ & 0.27 & $(0.04)$ \\
Saving deposits, > 3 months & 0.32 & $(0.04)$ & 0.60 & $(0.08)$ \\
TD, up to 2 years & 0.36 & $(0.04)$ & 0.66 & $(0.08)$ \\
TD, over 2 years & 0.40 & $(0.06)$ & 0.41 & $(0.10)$ \\
Weighted average & 0.16 & $(0.02)$ & 0.32 & $(0.03)$ \\
\hline Lending rates & & & & \\
Business, up to 1 year & 0.27 & $(0.04)$ & 0.69 & $(0.15)$ \\
Business, over 1 year & 0.47 & $(0.07)$ & 0.55 & $(0.08)$ \\
Mortgage, households & 0.35 & $(0.06)$ & 0.53 & $(0.09)$ \\
Households, short-term & 0.09 & $(0.05)$ & 0.43 & $(0.09)$ \\
Weighted average & 0.34 & $(0.05)$ & 0.48 & $(0.06)$ \\
\hline \hline
\end{tabular}

Notes: TD abbreviates Time Deposits. Standard errors in parentheses. The standard errors for the long-term pass-through are calculated according to the delta method (see e.g. Greene, 2000, p. 330).

change are on average passed on to borrowers, while 50 percent are absorbed by the banking sector.

From this we conclude that the long-run pass-through is more complete in the U.S. than in the euro area. While the pass-through from money market rates to bank deposit rates is nearly complete in the U.S., it amounts on average to 0.32 in the euro area. Moreover, the comparison between the weighted averages of the lending rates in the two economies also suggests that the long-run pass-through to lending rates is smaller in the euro area (0.48) than in the U.S. (0.57). However, this difference is not statistically significant. 


\section{Discussion}

Ultimately, the goal of this paper is to analyze how the pass-through process to retail interest rates influences equilibrium determinacy and macroeconomic stability. However, a precise quantitative evaluation appears difficult for the following reason: It is not clear to what extent retail interest rates as opposed to market interest rates (e.g. bond yields) are relevant for the determination of aggregate demand. Only a fraction of the households and firms in the economy relies on financial intermediaries, whereas the rest participates in financial markets directly. If the limited pass-through to retail rates is indeed due to the formation of relationships and implicit contracts, it follows that market rates in general should follow policy rates more closely. Assuming that at least the long-run pass-through from policy rates to market rates is close to complete, the overall pass-through to interest rates more generally is likely to be higher than to retail rates.

For the U.S., the long-run pass-through, $\lambda$, is nearly complete for most categories of deposit rates and on average approximately 0.57 for lending rates. Thus, our empirical results suggest that $\bar{\kappa}_{\pi}$, the lower bound for $\kappa_{\pi}$, consistent with a determinate equilibrium, lies between unity and 1.75 in the U.S. ${ }^{8}$ However, the banking sector and therefore retail rates play only a relatively minor role for the determination of U.S. aggregate demand (see e.g. Allen and Gale, 2000; De Fiore and Uhlig, 2005). Thus, we may conclude that $\bar{\kappa}_{\pi}$ is likely to lie substantially closer to the lower bound of this interval.

In the euro area, the average long-run pass-through appears to be lower than in the U.S. Consequently, larger values of $\kappa_{\pi}$ are needed for determinacy. Our estimate of the average pass-through to lending rates suggests a value

\footnotetext{
${ }^{8}$ Note that this calculation assumes $\kappa_{y}=0$. For empirically plausible values of $\kappa_{y}$, differences are negligible.
} 
for $\bar{\kappa}_{\pi}$ of approximately two. Looking at the average pass-through to deposit rates suggests an even larger value of around three. Again, the overall passthrough to interest rates relevant for aggregate demand and macroeconomic stability is likely to be higher. Therefore, these numbers for $\bar{\kappa}_{\pi}$ should be interpreted as upper bounds. However, in a bank-based system like the the one in the euro area, the difference should not be as large as in the U.S. Overall, the higher pass-through to U.S. retail rates together with the smaller relative size of the U.S. banking sector suggest that $\bar{\kappa}_{\pi}$ is lower in the U.S. than in the euro area.

How do our results compare to empirically estimated interest rate rule coefficients? For the U.S., Clarida et al. (2000) find a value of 2.15 for $\kappa_{\pi}$ for the Volcker-Greenspan period. Based on real-time-data Orphanides (2005) reports lower values of around 1.8. For the euro area, Gerdesmeier and Roffia (2004) estimate several specifications. Based on their preferred specification they obtain estimates ranging from 1.9 to 2.2. A precise evaluation is again complicated and the caveats mentioned above have to be kept in mind. However, the estimated values for $\kappa_{\pi}$ appear to fall within the determinate region for both economies. Nevertheless the euro area, with its more bank-based system, may be closer to the indeterminate region than the U.S.

\section{Concluding Remarks}

The influence of monetary policy on aggregate demand and inflation depends on the degree to which changes in policy interest rates are 'passed through' to market and retail interest rates. In this paper we focus on the possibility of sunspot fluctuations that arise from self-fulfilling revisions to expectations. If the pass-through from policy to retail interest rates is incomplete in the long run, the standard Taylor principle turns out to be insufficient for equilibrium 
determinacy. Our empirical estimates indicate that this result is particularly relevant for bank-based financial systems like that in the euro area.

Nevertheless, our quantitative results have to be interpreted with some caution, since it is not clear to what extent aggregate demand is sensitive to retail interest rates as opposed to market interest rates. Despite this caveat, we interpret our results as casting some doubt on the usual interpretation of interest rule coefficients and their implications for macroeconomic stability. 


\section{A Data Description}

Table A1: Money Market and Retail Interest Rates

\begin{tabular}{|c|c|c|c|}
\hline \multirow{2}{*}{ U.S. } & Source & Codes & Time Period \\
\hline & & & \\
\hline \multicolumn{4}{|l|}{ Deposit rates } \\
\hline TCD, 1 month & BIS & HPEAUS12 & 1995:01 - 2003:09 \\
\hline TCD, 3 months & BIS & HPEAUS02 & 1995:01 - 2003:09 \\
\hline TCD, 6 months & BIS & HPEAUS62 & 1995:01 - 2003:09 \\
\hline U.S. deposits, 1 year & IFS & $11160 \mathrm{LDF}$ & 1995:01 - 2003:09 \\
\hline \multicolumn{4}{|l|}{ Lending rates } \\
\hline Business, short-term & BIS & HLBAUS02 & 1995:01 - 2003:09 \\
\hline Mortgage, long-term & BIS & HLLAUS01 & 1995:01 - 2003:09 \\
\hline Consumers, short-term & Fed & G.19 & 1995:01 - 2003:09 \\
\hline Weighted average & & & 1995:01 - 2003:09 \\
\hline \multicolumn{4}{|l|}{ Money market rate } \\
\hline Money market, 3 months & BIS & JFBAUS02 & 1995:01 - 2003:09 \\
\hline \multicolumn{4}{|l|}{ Euro area } \\
\hline \multicolumn{4}{|l|}{ Deposit rates } \\
\hline Sight deposits & BIS & HPBAXM02 & 1995:12 - 2003:09 \\
\hline Saving deposits, $<3$ months & BIS & HPHAXM16 & 1995:01 - 2003:09 \\
\hline Saving deposits, $>3$ months & BIS & HРНАХМ36 & 1995:01 - 2003:09 \\
\hline TD, up to 2 years & BIS & HPFAXM16 & 1995:12 - 2003:09 \\
\hline TD, over 2 years & BIS & HPFAXM26 & 1995:12 - 2003:09 \\
\hline Weighted average & & & 1995:12 - 2003:09 \\
\hline \multicolumn{4}{|l|}{ Lending rates } \\
\hline Business, up to 1 year & BIS & HLBAXM12 & $1995: 12-2003: 09$ \\
\hline Business, over 1 year & BIS & HLHAXM02 & 1996:11 - 2003:09 \\
\hline Mortgage, households & BIS & HLMAXM22 & 1995:12 - 2003:09 \\
\hline Households, short-term & BIS & HLBAXM22 & 1995:12 - 2003:09 \\
\hline Weighted average & & & 1996:11 - 2003:09 \\
\hline Money market rate & & & \\
\hline Money market, 3 months & BIS & JFBAXM02 & 1995:01 - 2003:09 \\
\hline
\end{tabular}

Notes: TCD abbreviates Time Certificates of Deposit and TD Time Deposits. BIS stands for the Data Bank of the Bank for International Settlements. IFS stands for the International Financial Statistics of the International Monetary Fund and Fed stands for the monthly statistical release of the Board of Governors of the Federal Reserve System of the U.S.

\section{B Unit Root and Cointegration Test Results}




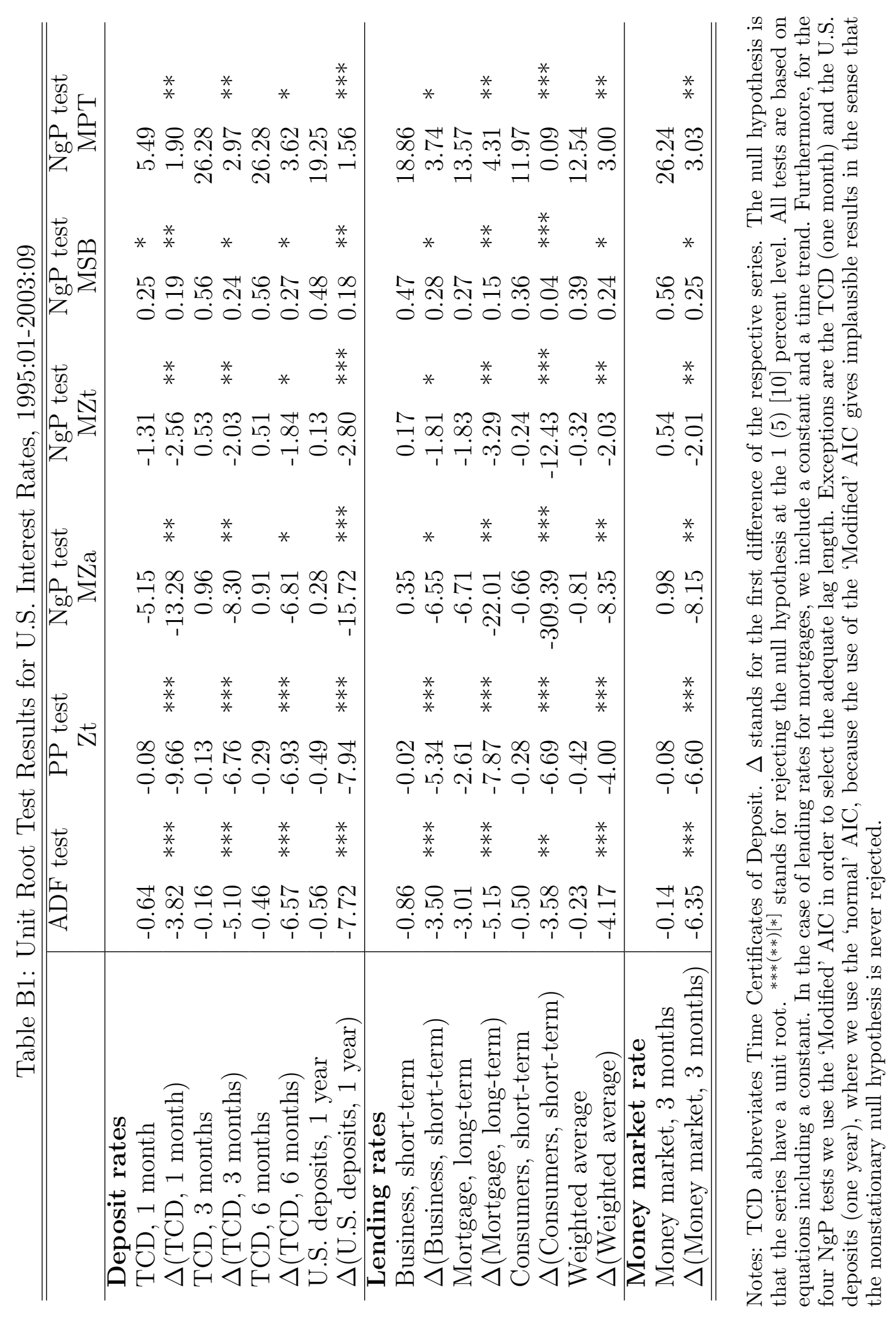




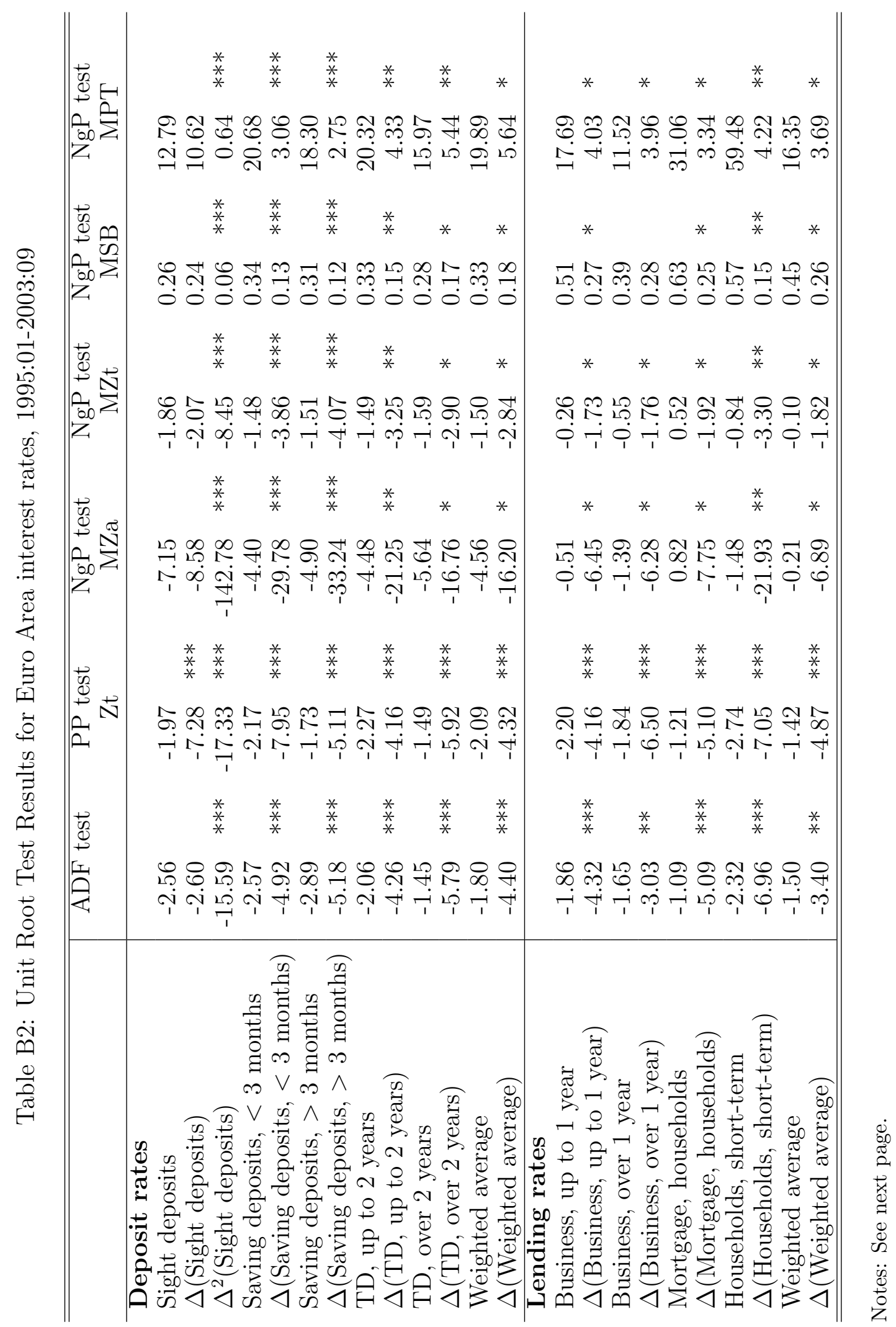




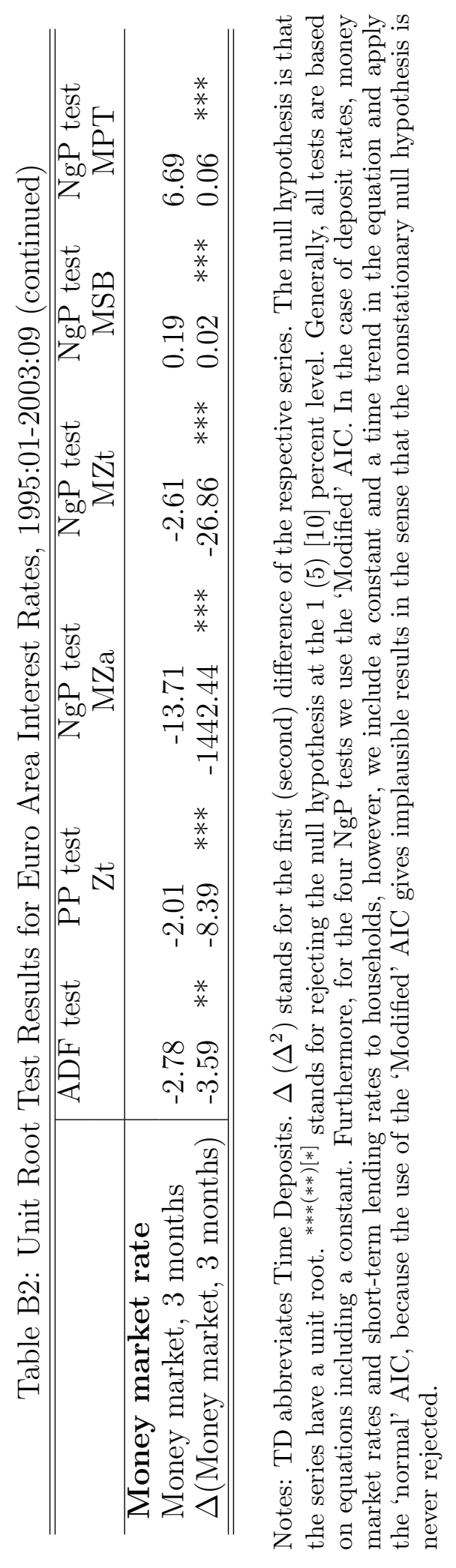




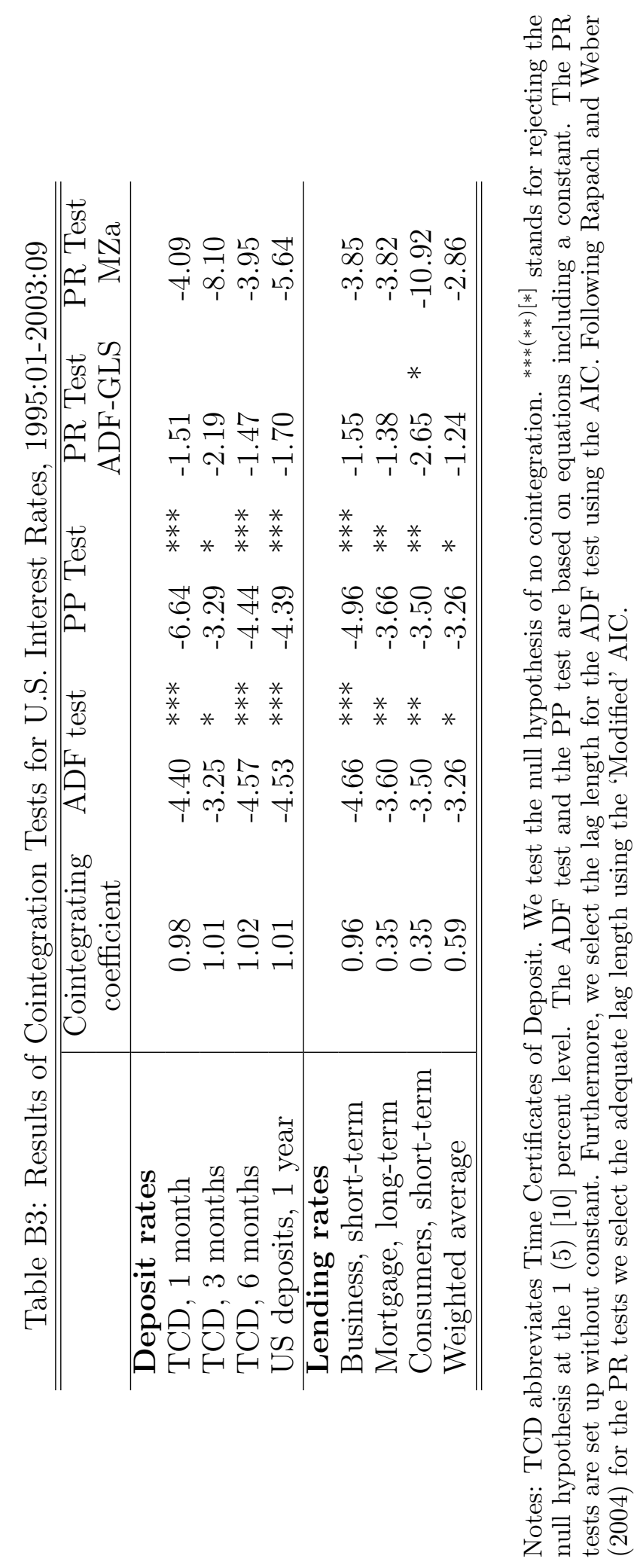




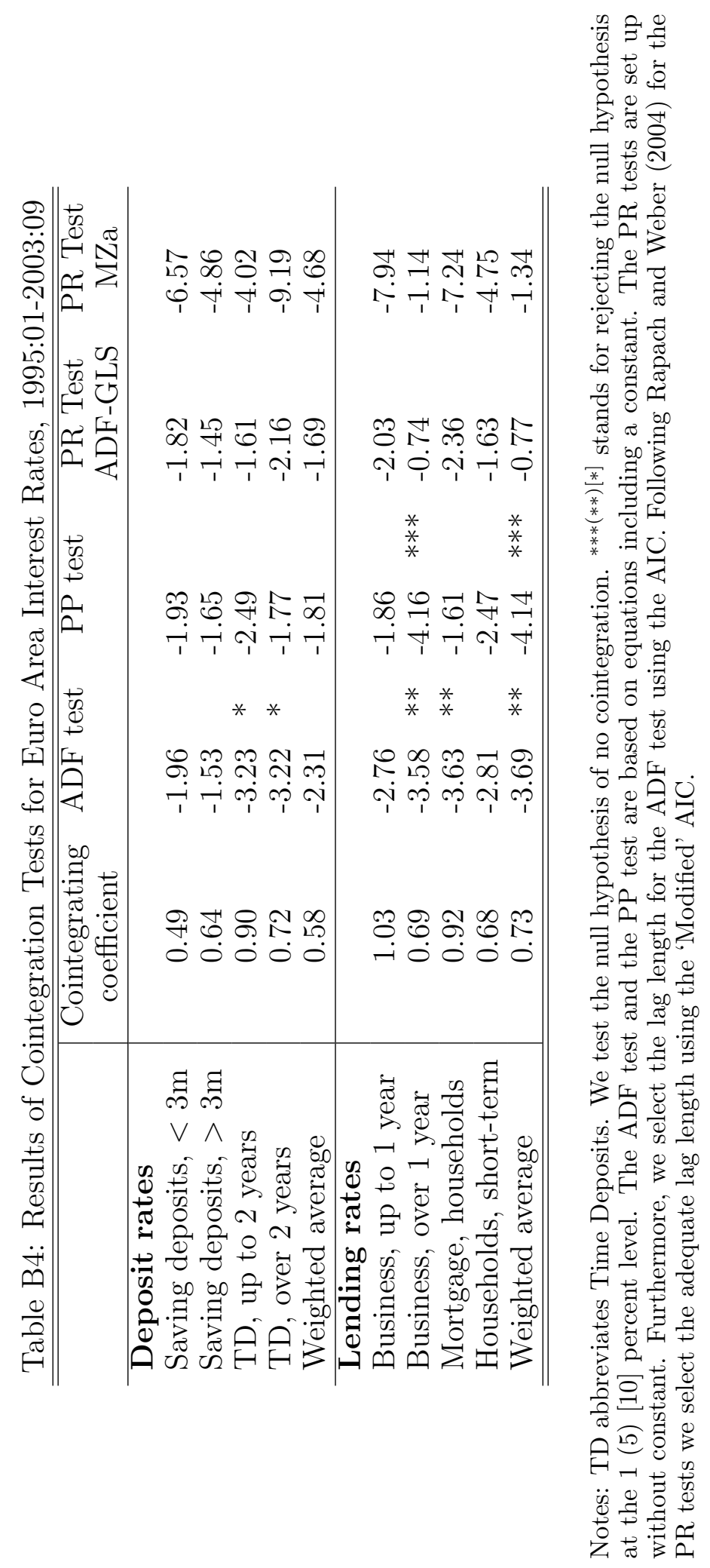




\section{References}

Allen, F., Gale, D., 2000. Comparing Financial Systems. MIT Press, Cambridge, MA.

Berger, A. N., Udell, G. F., 1992. Some evidence on the empirical significance of credit rationing. Journal of Political Economy 100 (5), 1047-1077.

Bhargava, A., 1986. On the theory of testing for unit roots in observed time series. Review of Economic Studies 53 (3), 369-384.

Blanchard, O., Kahn, C., 1980. The solution of linear difference models under rational expectations. Econometrica 48 (5), 1305-1312.

Clarida, R., Galí, J., Gertler, M., 1999. The science of monetary policy: A new keynesian perspective. Journal of Economic Literature 37 (4), 16611707.

Clarida, R. H., Galí, J., Gertler, M., 1998. Monetary policy rules in practice: Some international evidence. European Economic Review 42 (6), 10331067.

Clarida, R. H., Galí, J., Gertler, M., 2000. Monetary policy rules and macroeconomic stability: Evidence and some theory. Quarterly Journal of Economics 115 (1), 147-180.

De Bondt, G., 2005. Interest rate pass-through: Empirical results for the euro area. German Economic Review 6 (1), 37-78.

De Fiore, F., Liu, Z., 2005. Does trade openness matter for aggregate instability? Journal of Economic Dynamics and Control 27 (7), 1165-1192. 
De Fiore, F., Uhlig, H., 2005. Bank finance versus bond finance: What explains the differences between the US and Europe? CEPR Discussion Papers 5213.

Dickey, D., Fuller, W., 1979. Distribution of the estimators for autoregressive time series with a unit root. Journal of the American Statistical Association 74 (366), 427-431.

Edge, R., Rudd, J. B., 2002. Taxation and the Taylor principle. Finance and Economics Discussion Series 2002-51, Federal Reserve Board.

Ehrmann, M., Gambacorta, L., Martinez-Pages, J., Sevestre, P., Worms, A., 2003. The effects of monetary policy in the euro area. Oxford Review of Economic Policy 19 (1), 58-72.

Elliot, G., Rothenberg, T., Stock, J., 1996. Efficient tests for an autoregressive unit root. Econometrica 64 (4), 813-836.

Engle, R., Granger, C., 1987. Co-integration and error correction: Representation, estimation and testing. Econometrica 55 (2), 251-276.

Galí, J., Gertler, M., Lopéz-Salido, J. D., 1999. Inflation dynamics: A structured econometric investigation. Journal of Monetary Economics 44 (2), $195-222$.

Galí, J., Gertler, M., Lopéz-Salido, J. D., 2001. European inflation dynamics. European Economic Review 45 (7), 1237-1270.

Galí, J., Lòpez-Salido, D. J., Vallés, J., 2004. Rule-of-thumb consumers and the design of interest rate rules. Journal of Money, Credit and Banking 36 (4), 739-764. 
Gerdesmeier, D., Roffia, B., 2004. Empirical estimates of reaction functions for the Euro Area. Swiss Journal of Economics and Statistics 140 (1), 3766.

Greene, W., 2000. Econometric Analysis. Prentice Hall International, Inc.

Judd, J. F., Rudebush, G. D., 1998. Taylor's rules and the Fed. Federal Reserve Bank of San Francisco Economic Review, 3-16.

Leith, C., Malley, J., 2005. Estimated general equilibrium models for the evaluation of monetary policy in the US and Europe. European Economic Review 49 (8), 2137-2159.

Ng, S., Perron, P., 2001. Lag length selection and the construction of unit root tests with good size and power. Econometrica 69 (6), 1519-1554.

Orphanides, A., 2002. Monetary-policy rules and the great inflation. American Economic Review 92 (2), 115-120.

Orphanides, A., 2003. Monetary policy evaluation with noisy information. Journal of Monetary Economics 50 (3), 605-631.

Orphanides, A., 2005. Monetary policy rules, macroeconomic stability and inflation: A view from the trenches. Journal of Money, Credit, and Banking, forthcoming.

Perron, P., Rodriguez, G., 2001. Residual based tests for cointegration with GLS detrended data. Manuscript Boston University and Université d'Ottawa.

Phillips, P., 1987. Time series regression with a unit root. Econometrica 55 (2), 277-302. 
Phillips, P., Ouliaris, S., 1990. Asymptotic properties of residual based tests for cointegration. Econometrica 58 (1), 165-193.

Phillips, P., Perron, P., 1988. Testing for a unit root in time series regression. Biometrika 75 (2), 335-346.

Rapach, D., Weber, C., 2004. Are real interest rates really nonstationary? New evidence from tests with good size and power. Journal of Macroeconomics 26 (3), 409-430.

Roisland, O., 2003. Capital income taxation, equilibrium determinacy, and the Taylor principle. Economics Letters 81 (2), 147-153.

Said, S., Dickey, D., 1984. Testing for unit roots in autoregressive-moving average models of unknown order. Biometrika 71 (3), 599-607.

Taylor, J. B., 1999. A historical analysis of monetary policy rules. In: Taylor, J. B. (Ed.), Monetary Policy Rules. University of Chicago Press, Chicago, pp. 1305-1311.

Woodford, M., 2003. Interest and Prices: Foundations of a Theory of Monetary Policy. Princeton University Press. 